lente metáfora da luta pelo poder nas organizaçôes? The Good Soldier é uma maravilhosa análise da solidão nas classes altas. Lido em inglês, requer um bom domínio da língua. Ford näo faz concessöes. Mas, ainda que se tenha que ler com o dicionário do lado, é uma aula magna sobre o comportamento humano. Imperdivel para um bom administrador que queira compreender o profundamente humano.
Ford é um pescador de almas. Como termina Ford: "Foi uma história muito interessante: poderia ter sido ainda mais interessante se eles tivessem cavado seus olhos com facas pontiagudas; mas eles eram 'such a good people". Ford pode nấo ter produzido uma obra proustiana, mas certamente oleitor que se delicia com a leitura de Machado, lerá com prazer The Good Soldier. Afinal, gerir organizações não nos obriga a entender as razöes humanas? 'J

\title{
TRABALHO \& SOCIEDADE: PROBLEMAS ESTRUTURAIS E PERSPECTIVAS PARA O FUTURO DA "SOCIEDADE DO TRABALHO"
}

\section{Traduzido por Gustavo Bayer E. Margrit Martincic. Rio de Janeiro Tempo Brasileino OFFE 180 páginas, vol. 2 (Bibtioteca Tempo Universitário n 89 , Série Estudos Alemäes).}

Por Tarclla Luzia da SIlva, Doutoranda em Administraçăo pela EAESPIFGV a Professora da Universidade Federal do Mato Grosso do Sul.

- Por José Carlos Barblerl, Professor do Departamento de Administração de Produção e Operações Industriais da EAESP/FGV e Professor na Área de Administração e Economia na Universidade Federal do Mato Grosso do Sul (UFMS/CCHS).

D esde a década de 40 está presente nas Ciências Sociais a hipótese de que a partir de um certo grau de industrialização, a tendência de desenvolvimento da "Sociedade industrial" se alteraria no sentido de expansão do setor "terciário". Os indicadores usados para verificar e confirmar essa hipótese são, principalmente, o peso do setor de serviços no produto interno e a participação da força de trabalho do setor de serviços na populaçăo economicamente ativa. São exemplos: os trabalhos de Clark (1940), Stigler (1956) e Fuchs (1968), que contribuíram de modo significativo para o reconhecimento $\mathrm{da}$ importância do setor de serviços nas sociedades modernas. Para esse último autor a economia norte-americana havia se transformado na primeira economia de serviços do mundo, ou seja, havia passado de uma economia industrial para uma outra onde a maioria de sua população economicamente ativa encontravase empregada nas atividades de serviços. Trabalhos como esses contribuíram para formar uma corrente de pensamento que entende ser o setor de serviços o setor determinante do dinamismo da economia como um todo, substituindo o papel que desempenhara o setor industrial.

Essa tendência gerou, principalmente entre cientistas sociais norte-americanos, interpretaçōes genéricas e abrangentes cunhando conceitos como: "sociedade administrada", "sociedade pós-industrial", ou ainda "sociedade dos serviços pessoais".

Claus Offe elaborou esse trabalho a partir da observação do uso genérico desses conceitos, verificando a necessidade de se questionar essa conceituaçăo que parte de definiçôes enumerativas para chegar a "não conceitos" do que seja serviços, ou seja, serviço definido como resíduo.

Na primeira parte do livro Crescimento e Racionalização do Setor de Serviços, Offe dedica-se a analisar o comportamento desse setor através de uma classificação desconhecida na ampla literatura sobre o tema e, partindo dessa 
classificação, analisa esse setor considerando os fatores dinâmicos do seu desenvolvimento e as características sociológicas do trabalho aí praticado.

Apontando as deficiências conceituais dessas formulações sobre a "sociedade pós-industrial", Offe analisa o setor de serviços tendo como ponto de partida uma definição funcional do setor. Essa abordagem permite a análise do setor na sua determinação sociológica.

O pressuposto para essa definição funcional é de que o setor de serviços abrange a totalidade das funções dentro das quais se realiza a reprodução material da sociedade, compreendendo a manutenção de condições físicas da vida social, dos sistemas de normas culturais e legais, a transmissão e o desenvolvimento do acervo de conhecimentos de uma sociedade, seus sistemas de informação e de circulação.

A partir da hipótese de que os serviços em geral possam ser descritos como atividades de manutenção das estruturas sociais formais, discute-se a composição interna do setor, tendo como critério o seu distanciamento estrutural do trabalho produtivo, a saber: serviços comerciais, serviços internos à organização e serviços públicos e estatais. Trata-se, portanto, de uma classificação única na extensa literatura sobre o assunto, pois essa classificação inclui as atividades de serviços desenvolvidas pelos setores industriais tais como: manutenção, administração de materiais, transporte etc. Essa classificação retoma a discussão sobre trabalho produtivo e improdutivo e questiona as reais dificuldades de se medir a produtividade desses serviços, uma vez que sua razão de ser é o acompanhamento do processo de produção de mercadorias. Aponta, nesse aspecto ainda, a relevância do critério de classificação dos serviços quanto à sua rentabilidade e custos, em comparação com as demais atividades produtivas. Enfoca-se todos os aspectos resultantes dessa atividade "reguladora", assim como as possibilidades de racionalização nesse setor.

$\mathrm{Na}$ seqüência, o autor aponta os fatores que interferem no desenvolvimento dos serviços, pontuando as dificuldades na determinação do crescimento e da contração desse setor. Esses fatores são: a demanda dos clientes, a demanda da força de trabalho e a demanda da produção. As conseqüências sociais do crescimento/redução dos serviços na sociedade capitalista e as explicações sociológicas para o crescimento do trabalho nos serviços também estão presentes.

Na segunda parte do livro Estado de Bem-estar e Desemprego, Offe relata as críticas da direita e da esquerda em relaçäo ao Estado de bem-estar social e sugere que esse Estado, diretamente dependente do crescimento e rentabilidade da economia, tornou-se um poder amortecedor irreversível para o capitalismo europeu. Com essa afirmação o autor polemiza com as idéias neo-liberais que sustentam ser o Estado de Bem-estar Social um obstáculo à retomada do crescimento capitalista. Nessa análise, o autor reconhece uma contradição impossível de ser resolvida, pois o capitalismo não pode coexistir com o Estado de Bem-estar Social e nem pode continuar existindo sem ele. Essa contradiçāo básica é que faz com que surjam, em determinados períodos, políticas como as de Tatcher (na Inglaterra) e Reagan (nos EUA) que procuram desmontar o Estado de Bem-estar Social criado em períodos anteriores. As observações de Offe são muito pertinentes para aqueles que se propõem a entender as políticas de "desestatização" e desregulamentação em voga no atual momento.

Essa segunda parte do livro complementa a primeira e constitui um importante referencial para a análise das questões relacionadas com a expansão ou retração do setor de serviços, principalmente com respeito ao setor de serviços públicos e estatais.

Pela abrangência da análise e pelo diferencial que apresenta em relação às outras publicações no gênero, esse trabalho de Claus Offe torna-se obrigatório para todos que pretendem aprofundar estudos sobre os problemas estruturais da "Sociedade de Trabalho", bem como discutir o papel do Estado nessa nova fase de reestruturação do capitalismo. J

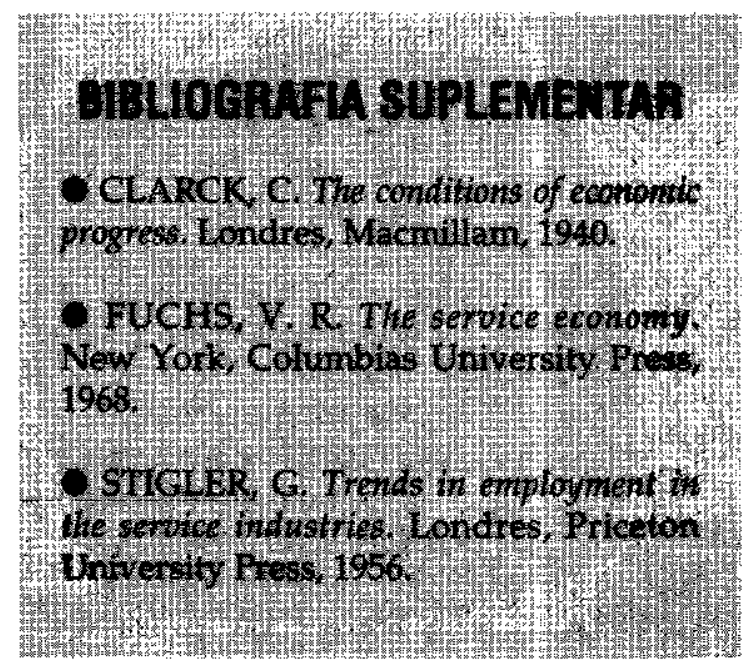

